\title{
Silencing of LSD1 gene modulates histone methylation and acetylation and induces the apoptosis of JeKo-1 and MOLT-4 cells
}

\author{
ZHONG-KAI ZOU ${ }^{1}$, YI-QUN HUANG ${ }^{2}$, YONG ZOU $^{2}, \mathrm{XU}_{-K E} \mathrm{ZHENG}^{2}$ and XU-DONG MA ${ }^{2}$ \\ Departments of ${ }^{1}$ Pathology and ${ }^{2}$ Hematology, Zhangzhou Affiliated Hospital of \\ Fujian Medical University, Zhangzhou, Fujian 363000, P.R. China
}

Received November 4, 2015; Accepted May 24, 2017

DOI: $10.3892 / \mathrm{ijmm} .2017 .3032$

\begin{abstract}
Lysine-specific demethylase 1 (LSD1) has been identified and biochemically characterized in epigenetics; however, the pathological roles of its dysfunction in mantle cell lymphoma (MCL) and T-cell acute lymphoblastic leukemia remain to be elucidated. In this study, we evaluated LSD1, and histone $\mathrm{H} 3$ lysine 4 (H3K4)me1 and H3K4me2 expression in patients with MCL and silenced LSD1 in JeKo-1 and MOLT-4 cells, in order to define its role in JeKo-1 and MOLT-4 cell proliferation and apoptosis. We retrospectively analyzed the protein expression of LSD1, and mono- and dimethylated H3K4 (H3K4me1 and H3K4me2), and cyclin D1 and Ki67 in 30 cases of MCL by immunohistochemistry. The correlation of LSD1, H3K4me1 and H3K4me2 with Ki67 was determined by statistical analysis. LSD1 was silenced by small interfering RNA(siRNA).Cell apoptosis and cell proliferation were detected by flow cytometry and 3-(4,5-dimethylthiazol-2-yl)-2,5-diphenyltetrazolium bromide (MTT) assay. The protein expression levels of LSD1, histone methylated $\mathrm{H} 3 \mathrm{~K} 4$, histone acetylated H3, cyclin D1, apoptotic proteins, p15 and DNA methyltransferase 1 (DNMT1) were examined by western blot analysis. We demonstrated that LSD1 was upregulated, and that H3K4me1 and $\mathrm{H} 3 \mathrm{~K} 4 \mathrm{me} 2$ were downregulated in the cases with MCL, compared to those with proliferative lymphadenitis $(\mathrm{p}<0.05)$. LSD1 positively correlated with Ki67 in MCL [Cohen's kappa $(\kappa)=0.667, \mathrm{p}<0.01]$. There was no significant correlation between H3K4me1 and H3K4me2, and Ki67 ( $\kappa=-0.182$, p $>0.05$, $\kappa=-0.200, p>0.05)$. The silencing of LSD1 decreased the levels of the apoptosis-related proteins, Bcl-2, pro-caspase- 3 and C-myc, and decreased those of DNMT1 and increased p15, and resulted in the loss of cell viability and the induction apoptosis.
\end{abstract}

Correspondence to: Dr Xu-Dong Ma, Department of Hematology, Zhangzhou Affiliated Hospital of Fujian Medical University, 59 Shengli Road, Zhangzhou, Fujian 363000, P.R. China

E-mail: maxuong_11@163.com

Key words: small interfering RNA, lysine-specific demethylase 1, histone methylation, mantle cell lymphoma, JeKo-1, MOLT-4, apoptosis
The silencing of LSD1 increased the expression of H3K4me1 and $\mathrm{H} 3 \mathrm{~K} 4 \mathrm{me} 2$, and histone acetylated $\mathrm{H} 3$ in the JeKo-1 and MOLT-4 cells. LSD1 siRNA also decreased cyclin D1 expression in the JeKo-1 cells. On the whole, our findings demonstrate that the overexpression of LSD1 may be associated with the pathogenesis in MCL. We demonstrated that the silencing of LSD1 is capable of removing the mono- and dimethyl groups from $\mathrm{H} 3 \mathrm{~K} 4$, and upregulating the histone acetylation of $\mathrm{H} 3$ in JeKo-1 and MOLT-4 cells. The silencing of LSD1 inhibited cell growth and induced cell apoptosis. Of note, in JeKo-1 cells, the silencing of LSD1 decreased cyclin D1 expression, which is one of the genes that contribute to the pathogenesis of MCL. LSD1 may thus be a possible therapeutic target in MCL and acute lymphoblastic leukemia MOLT-4 cells.

\section{Introduction}

In recent years, epigenetics has become a hot topic in cancer research. The balance of methylation and demethylation in epigenetic modification affects gene expression and cellular activity. Studies have demonstrated that aberrant histone lysine methylation in cancer is associated not only with the repression of chromatin related to specific genes, but also with the repression of large chromosomal regions (1). Epigenetic alterations in lysine-specific demethylase 1 (LSD1; also known as KDM1A) have been shown to play a key role in carcinogenesis (2). As LSD1 belongs to the flavin-dependent amine oxidase family, LSD1 specifically catalyzes the demethylation of mono- and dimethylated histone H3 lysine 4 (H3K4) and H3 lysine 9 (H3K9) through a redox process. LSD1 is overexpressed in many solid tumors such as breast, colon, neuroblastoma, bladder, small cell lung and prostate cancers (3-7) and plays an important role in leukemia (8), attracting steadily increasing attention as a major target for epigenetic drug discovery (9-11). To date, only few studies have implicated LSD1 in mantle cell lymphoma (MCL) and T-cell acute lymphoblastic leukemia (T-ALL) (12).

MCL is a type of non-Hodgkin's lymphoma (NHL), comprising approximately $6 \%$ of all NHL cases. MCL cells generally overexpress cyclin D1 due to a $\mathrm{t}(11 ; 14)(\mathrm{q} 13 ; \mathrm{q} 32)$ chromosomal translocation, which plays an important role in the pathogenesis of the disease. These cases exhibit a higher proliferative activity and a more aggressive clinical evolution (13). Conventional therapy leads to complete remission in only $10-15 \%$ of patients. T-ALL, which accounts for $25 \%$ of cases 
of adult ALL, is characterized by the malignant clonal expansion of immature T-cell progenitors (14). These are aggressive malignancies that do not respond well to chemotherapy and have a poorer prognosis than their B cell counterparts.

In this study, we investigated the state of LSD1 and the histone methylation of H3K4me1 and H3K4me2 in MCL. We also examined the correlation of LSD1 and H3K4me1 and H3K4me2 with Ki67, which is prognostic marker in MCL. Furthermore, we silenced LSD1 using small interfering RNA (siRNA) and measured consequent histone modification, gene transcription, cell proliferation and apoptosis in JeKo-1 and MOLT- 4 cells.

\section{Materials and methods}

Patients and specimens. Surgical specimens from 30 patients with MCL obtained at the Zhangzhou Affiliated Hospital of Fujian Medical University, Zhangzhou, China between January 2005 and December 2010, were retrospectively collected for analysis. Lymphoid tissue samples were collected from all participants after obtaining written informed consent. This study was approved by the Ethics Committee of Zhangzhou Affiliated Hospital of Fujian Medical University. Diagnosis was made according to the WHO classification. In all 30 cases of MCL, cyclin D1 was overexpressed. Samples of patients with hyperplastic lymphadenitis $(n=30)$ were used as controls. None of the patients had received radiotherapy or chemotherapy prior to surgery.

Antibodies. Antibodies for rabbit against human monomethylated H3K4 (cat. no. 07-436), dimethylated H3K4 (cat. no. 07-030) and trimethylated H3K4 (cat. no. 07-992), rabbit against human acetylation H3 (cat. no. 07-677-I), and rabbit against human LSD1 (cat. no. 07-705) were purchased from Upstate Biotechnology (Lake Placid, NY, USA); antibodies for cyclin D1 (EP12) and Ki67 (MIB1) were from (Dako, Glosrup, Denmark). Antibodies for Bcl-2 (cat. no. sc-578), Bax (cat. no. sc-20067), pro-caspase-3 (cat. no. sc-22139), C-myc (cat. no. sc-4084), p15 (cat. no. sc-271791), DNMT1 (cat. no. sc-514784) and $\beta$-actin (cat. no. sc-8432) were from Santa Cruz Biotechnology, Inc. (Santa Cruz, CA, USA).

Tissue microarray (TMA) construction and immunohistochemistry. The archival formalin-fixed and paraffin wax-embedded tissue blocks of $30 \mathrm{MCL}$ and 30 hyperplastic lymphadenitis samples were removed by surgery. A representative tumor paraffin block (donor block) was collected from each case, and two tissue cores ( $2 \mathrm{~mm}$ in diameter) were obtained using a trephine apparatus. Trephinated paraffin tissue cores were then arranged in a new recipient paraffin block (tissue array block). Cores containing tumors in $>50 \%$ of the area were considered adequate. Immunohistochemical staining was performed using commercial polyclonal rabbit antibodies to histone demethytransferase LSD1, and mono- and dimethyl histone H3K4, Ki67 and cyclin D1. Tissue array blocks were sectioned at a thickness of $4 \mu \mathrm{m}$ and mounted on pre-coated glass slides. The sections were deparaffinized and hydrated prior to immunohistochemistry. The immunohistochemical SP method was performed according to the manufacturer's instructions. Tissues positive for all the purchased antibodies were used as positive controls.
Negative control staining was carried out by substituting nonimmune rabbit and phosphate-buffered saline (PBS) for the primary antibodies. The positive control exhibited brown color in the nuclei. Chevallier's semi-quantity system analysis was used in the calculation of the results of immunohistochemistry. For LSD1, mono and dimethylated histone H3K4, the results are presented as the sum of scores presenting color density and the percentage of stained cells. According to color density, nonstained cells were scored as 0 , slightly stained were scored as 1 , intermediate-stained werescored as 2 and strongly stained were scored as 3 . When the number of positive cells was $<25,25-50$, or $50-75$, or $>75 \%$, the immunoreactivity was scored as $0,1+, 2+, 3+$ and $4+$, respectively. The two scores of presenting color density and the number of positive cells were added for each slide. The sum that was 0 was negative, $1-2$ was presented as,$+ 3-4$ as ++ , $5-6$ as +++ , and 7 as ++++ . If the sum of the two scores was $<2$, it was considered negative staining and $>2$ was considered positive staining. The scores of each patient group were averaged.

The Ki67 index was defined as the percentage of Ki67positive tumor cells in representative areas of the lymphoma. To count the number of Ki67-positive cells, 2 representative areas were selected. A representative area was defined not to contain residual germinal centers, hot spots of proliferation or proliferating T-cells. Hot spots of proliferation were areas of tumor cells of $<2$ high-power fields in size (field of vision at x400 magnification), which proliferate higher than the rest of the tumor. Counting was performed by one observer. The positive cells among 500 cells were counted using an eyepiece with a grid in a 40X objective. The Ki67 index was calculated as the percentage of positive cells by averaging the values obtained for the 2 areas (count-Ki67 index) with a semi-quantitative evaluation system, consisting of 4 levels: $<10,10-30,30-50$ and $>50 \%$ labeled cells. Negative control staining was obtained by omitting the primary antibodies.

Cell culture. The human MCL JeKo-1 (MCL) and MOLT-4 (acute lymphoblastic leukemia) cell lines used in this study were purchased from the Shanghai Institute of Cell Bank (Shanghai, China). The cells were cultured in $10 \%$ fetal bovine serum, and RPMI-1640 containing $2 \mathrm{mM}$ L-glutamine under $37^{\circ} \mathrm{C}$, saturated humidity and $5 \% \mathrm{CO}_{2}$. The cells were subcultured every 3-5 days. The cells were seeded and treated with the desired siRNA concentrations in different time points.

siRNA and transfection. The cells were seeded with $5 \times 10^{4}$ cells in 96-well plates, and incubated for 2-4 days in standard medium in the presence of $10-20 \mathrm{nmol} / 1$ siRNA directed against LSD1. The siRNA LSD1 sequences used in this study were as follows: siRNA LSD1 (sense, 5'-CCACGAGUCAAA CCUUUAUTT-3' and antisense, 5'-AUAAAGGUUUGACU CGUGGTT-3'), which was synthesized by Shanghai GenePharma Co., Ltd. (Shanghai, China); the cells were transfected using Lipofectamine ${ }^{\mathrm{TM}} 2000$ according to the manufacturer's instructions (Invitrogen, Carlsbad, CA, USA). Inducible JeKo- 1 and MOLT-4 cells $\left(1 \times 10^{5}\right.$ cells/well) were seeded onto 24-well plates (Costar Life Science, Acton, MA, USA) and transiently transfected with the desired concentrations of LSD1 siRNA. All experiments were conducted in triplicate using independent cultures. Both total RNA and protein were extracted at $24 \mathrm{~h}$ after transfection. 
Reverse transcription-polymerase chain reaction ( $R T-P C R)$. Total RNA was extracted from samples of $1 \times 10^{6}$ cells using TRIzol reagent (Invitrogen). The quantity and quality of the RNA samples were measured by absorbance at 260 and $280 \mathrm{~nm}$. RNA samples with an A260, A280 ratio of 1.8-2.0 were stored at $-80^{\circ} \mathrm{C}$ until use. Copy DNA synthesis was performed using an avian myeloblastosis virus reverse transcriptase kit, according to the manufacturer's instructions (Promega, Madison, WI, USA). $\beta$-actin was used as an internal control. The primers used in the PCR amplifications were: LSD1 forward, 5'-GTT GGAGAGTAGCCTCAAATGTC-3' and reverse, 5'-TGACC GGATGACTTCTCAAGA-3'; and $\beta$-actin forward, 5'-GAGA CCTTCAAGACCCCAGCC-3 and reverse, 5'-TCGGGG CATCGGAACCGCTCA-3'. In addition, the amplicon size was 155 basepairs (bp), 404 bp for LSD1 and $\beta$-actin, respectively. The PCR reaction conditions were: $95^{\circ} \mathrm{C}$ for $30 \mathrm{sec}, 60^{\circ} \mathrm{C}$ for $30 \mathrm{sec}, 72^{\circ} \mathrm{C}$ for $40 \mathrm{sec}$, and was repeated 32 cycles. PCR-amplified products were electrophoresed on $1.5 \%(\mathrm{w} / \mathrm{v})$ agarose gels with $1 \mu \mathrm{g} / \mathrm{ml}$ ethidium bromide. The experiments were repeated twice.

3-(4,5-Dimethylthiazol-2-yl)-2,5-diphenyltetrazolium bro mide (MTT) growth inhibition assay. To examine the effect of the silencing of LSD1 by siRNA on cell growth, cell viability assay was determined using MTT. The JeKo-1 and Motl-4 cells were seeded at a density of $1 \times 10^{5}$ cells/well in 96-well culture dishes (Costar Life Science) and treated with siRNA directed against LSD1. This was followed by transfection $(n=5)$ with the indicated concentrations of LSD1 siRNA at different time points in the JeKo-1 and MOLT-4 cells. Cell proliferation was measured by MTT assay $(0.5 \mathrm{mg} / \mathrm{ml}$; Sigma-Aldrich, St. Louis, MO, USA), which was accomplished as indicated. The spectrophotometric absorbance of the samples was determined using the Ultra Multifunctional Microplate Reader (Tecan, Durham, NC, USA) at 492 and $630 \mathrm{~nm}$ for absorbance (OD value). The inhibitionn ratio was also calculated. The experiment was repeated in triplicate. Cell proliferation rate $(\%)=\left(\mathrm{A}_{\text {experiment }}-\mathrm{A}_{\text {blank }}\right) /\left(\mathrm{A}_{\text {control }}-\mathrm{A}_{\text {blank }}\right) \times 100 \%$.

Evaluation of apoptosis by flow cytometry. Apoptosis assay was performed according to the manufacturer's instructions (BD Biosciences, San Jose, CA ,USA). A total of $1 \times 10^{6}$ cells/well were seeded in 6-well plates (Costar Life Science) with sterile cover glass placed at the bottom of each well, and then transfected with negative control siRNA, or 40,80 and $120 \mathrm{nmol} / 1$ of LSD1 siRNA for $24 \mathrm{~h}$, while at at the logarithmic phase (for JeKo-1 cells), and at 30, 60 and $120 \mathrm{nmol} / 1 \mathrm{LSD} 1 \mathrm{siRNA}$ for $24 \mathrm{~h}$ (for MOLT-4 cells). The cells were then resuspended in binding buffer and stained with Annexin V-FITC/propidium iodide (PI) following the manufacturer's instructions (BD Biosciences) by flow cytometry (Epics-XL; Beckman Coulter, Inc., Brea, CA, USA). A total of 10,000 events/sample were acquired on the FACScan. Fluorescent commissions were collected through 5.30 and $5.70 \mathrm{~nm}$ pass filters for FITC and PI, respectively. The measurements were performed independently at least 3 times with similar results.

Western blot analysis for the detection of the protein expression of LSD1, monomethylated $\mathrm{H} 3 \mathrm{~K} 4$, dimethylated $\mathrm{H} 3 \mathrm{~K} 4$, trimethylated $\mathrm{H} 3 \mathrm{~K} 4$ and Act-H3, and apoptosis-related proteins. Total protein lysis and western blot analysis were performed according to the instructions of the manufacturer (Pierce, Rockford, IL, USA). Briefly, the JeKo-1 and MOLT- 4 cells were plated on culture dishes and transfected with LSD1 siRNA at the indicated concentrations for the JeKo-1 and MOLT-4 cells for $24 \mathrm{~h}$. The control cells were incubated in medium with $\mathrm{Na}_{2} \mathrm{CO}_{3}$ using same the time points. Following transfection with siRNA LSD1, total proteins were prepared from each culture condition with lysis buffer (Pierce) containing freshly prepared protease inhibitors. Protein concentration was then measured using BCA protein assay (Pierce). Cell extracts were subjected to $12 \%$ SDS-PAGE and electrophoretically transferred onto nitrocellulose membranes. The membranes were incubated with monoclonal anti-mono-, di- and trimethylated histone H3K4, anti-histone acetylated H3, LSD1 (Upstate Biotechnology), Bcl-2, Bax, pro-caspase-3, C-myc, p15, DNMT1 and cyclin D1 (Santa Cruz Biotechnology, Inc.) antibodies. After being washed with TBS, the membranes were incubated with secondary antibodies conjugated with peroxidase [goat anti-rabbit (cat. no. sc-3837) and goat anti-mouse (cat. no. sc-395758) antibodies; Santa Cruz Biotechnology, Inc.]. The signal was then detected using the chemiluminescent detection system (Pierce) and analyzed by a color image analysis system (AlphaDigiDoc; Alpha Innotech).

Statistical analysis. All statistical calculations were performed using SPSS version 18.0 for Windows software (SPSS, Inc., Chicago, IL, USA). Data are presented as the means \pm SD. The t test was carried out to compare the levels of the parameters between 2 groups. Differences between the values were assessed for statistical significance using the Chi-square, Wilcoxon rank sum test, one-way analysis of variance (ANOVA) and repeated measure ANOVA to evaluate correlations between Ki67 and LSD1, and H3K4me1 and H3K4me2. Agreement measure was calculated by Cohen's kappa statistic $\kappa$. The statistical level of significance was set at the $5 \%$ level $(\mathrm{p}<0.05)$.

\section{Results}

High expression of LSD1 and lower expression of methylated H3K4mel and H3K4me2 in MCL. LSD1 expression is upregulated in MCL cancer tissues. We first examined the expression levels of LSD1 in $30 \mathrm{MCL}$ and 30 hyperplastic lymphadenitis (controls) by TMA staining. A high LSD1 expression was detected in the nuclei of malignant cells, while less staining was observed in the non-neoplastic tissues (Fig. 1). Specifically, high levels of LSD1 expression (score, $3+$ to $4+$ ) were observed in 15 out of the $30(50.0 \%)$ cases of MCL, and in $17 \%$ (5 out of 30) of the controls, indicating a significant elevation of LSD1 expression in MCL $(\mathrm{p}<0.01)$ (Table I). The expression of $\mathrm{H} 3 \mathrm{~K} 4 \mathrm{me} 1$ in the MCL cases was 33\% (10/30), lower than that in the controls $(71 \% ; 23 / 30 ; \mathrm{p}<0.01)$. The expression of H3K4me2 in the MCL cases was $10 \%$ (3/30), lower than that in the contr ols (47\%; 14/30; p<0.01) (Table I). Thus, we hypothesized that LSD1 may play an important role in the pathogenesis of MCL. In addition, the expression of cyclin D1 in the MCL cases was $100 \%$ positive, but that in the hyperplastic lymphadenitis cases was $100 \%$ negative. 


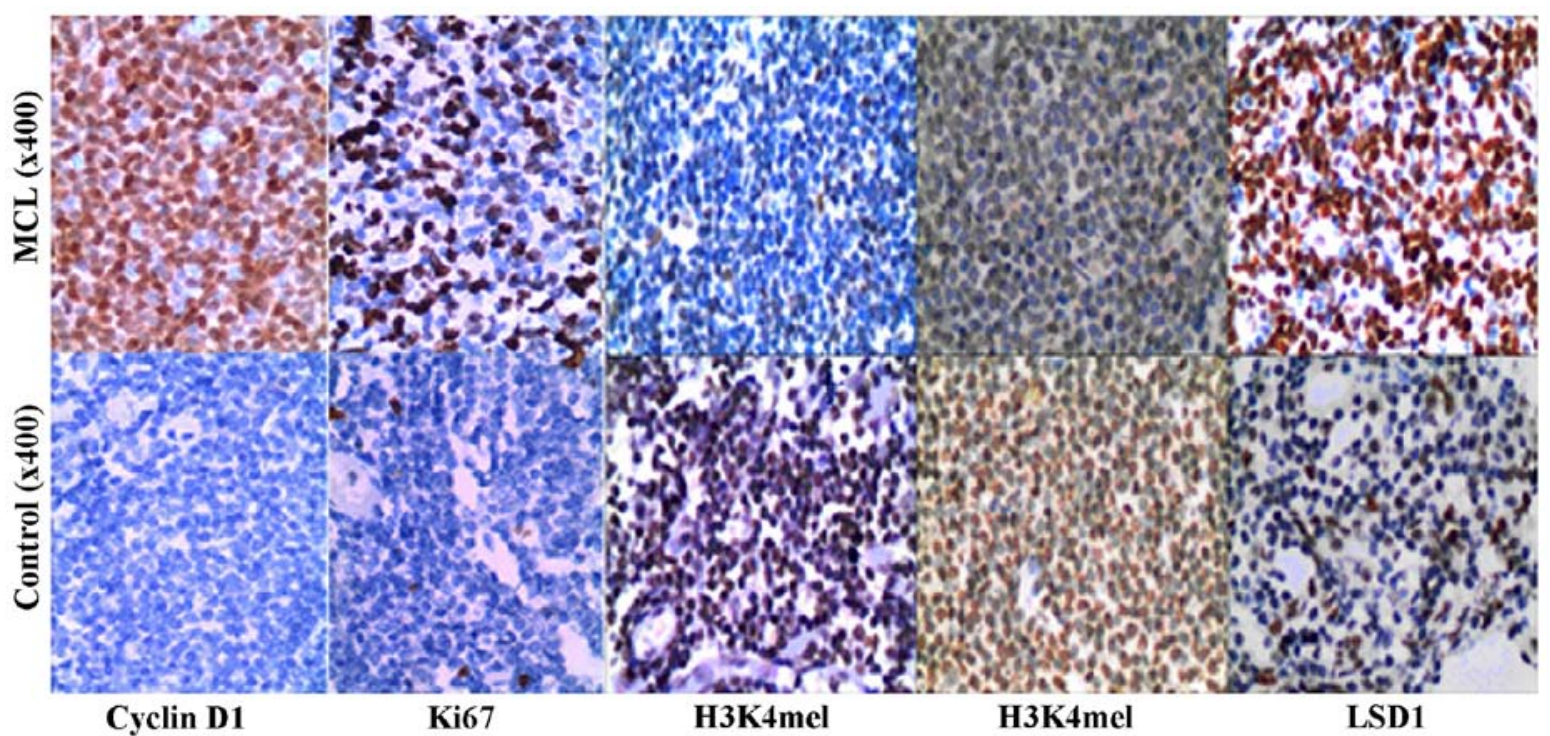

Figure 1. Expression of H3K4me1, H3K4me2 methylation, lysine-specific demethylase 1 (LSD1), Ki67 and cyclin D1 in mantle cell lymphoma (MCL). H3K4me1, H3K4me2 methylation, LSD1, Ki67 and cyclin D1 were detected by immunohistochemistry. Tissue microarray (TMA) was constructed and immunohistochemical staining was performed. Chevallier's semi-quantity system analysis was used in the calculation of immunohistochemistry results in histone H3K4me1, H3K4me2, LSD1 and cyclin D1. Ki-67 values obtained by the counting of 500 cells using an eyepiece with a grid in a 40X objective.

Table I. Expression of LSD1, H3K4me1 and H3K4me2 in MCL cases.

\begin{tabular}{|c|c|c|c|c|c|c|c|c|c|c|c|c|c|c|}
\hline & \multicolumn{5}{|c|}{ MCL cases $(n=30)$} & \multirow[b]{2}{*}{ Rate $(\%)$} & \multicolumn{5}{|c|}{ Control cases $(n=30)$} & \multirow[b]{2}{*}{ Rate (\%) } & \multirow[b]{2}{*}{$\chi^{2}$} & \multirow[b]{2}{*}{ P-value } \\
\hline & - & + & $2^{+}$ & $3^{+}$ & $4^{+}$ & & - & + & $2^{+}$ & $3^{+}$ & $4^{+}$ & & & \\
\hline LSD1 & 0 & 5 & 10 & 12 & 3 & 50.0 & 2 & 7 & 16 & 4 & 1 & 17 & 7.5 & 0.0062 \\
\hline $\mathrm{H} 3 \mathrm{~K} 4 \mathrm{me} 1$ & 3 & 3 & 14 & 9 & 1 & 33.3 & 0 & 1 & 6 & 19 & 4 & 71 & 11.38 & 0.0007 \\
\hline $\mathrm{H} 3 \mathrm{~K} 4 \mathrm{me} 2$ & 16 & 6 & 5 & 3 & 0 & 10.0 & 1 & 8 & 7 & 12 & 2 & 47 & 9.93 & 0.0016 \\
\hline
\end{tabular}

LSD1, lysine-specific demethylase 1; MCL, mantle cell lymphoma.

Table II. Expression of Ki67 in MCL cases.

\begin{tabular}{|c|c|c|c|c|c|c|}
\hline & \multicolumn{5}{|c|}{ Ki67 } & \multirow[b]{2}{*}{ P-value } \\
\hline & $\leq 10 \%$ & $11-30 \%$ & $31-50 \%$ & $>50 \%$ & Mean \pm SD & \\
\hline MCL, n (\%) & $20(66.7)$ & $5(16.7)$ & $2(6.7)$ & $3(10)$ & $12.53 \pm 23.70$ & $<0.05$ \\
\hline Control, n (\%) & $28(93.3)$ & $2(6.7)$ & 0 & 0 & $1.97 \pm 2.70$ & \\
\hline
\end{tabular}

MCL, mantle cell lymphoma.

Correlation of methylated H3K4me1 and H3K4me2, and LSD1 with Ki67 in MCL. To evaluate the clinical significance of LSD1 overexpression in MCL, we examined whether the expression levels of LSD1, H3K4mel and H3K4me2 correlated with Ki67, which is a poor prognostic factor in MCL. The Ki67 labeling index was $100 \%$ in MCL [ $\leq 10,66.7 \%$ (20/30; $11-30 \%$, $16.7 \%$ (5/30); 31-50\%, 6.7 (2/30); and $>50 \%, 10.0 \%$ (3/30)]. The mean index was $12.53 \pm 23.70 \%$. In hyperplastic lymphadenitis, the Ki67 score was as follows: $\leq 10,93.3 \%$ (28/30); and 11-30\%, only $6.7 \%$. The mean index was $1.97 \pm 2.70 \%$, p $<0.05$ (Fig. 1 and Table II). To evaluate the correlation of LSD1, H3K4me1 and H3K4me2 with Ki67, we examined the correlation between LSD1, H3K4me1 and H3K4me2 with Ki67 by statistical analysis. The data indicated that the Ki67 labeling index positively correlated with LSD1 $(\kappa=0.667, \mathrm{p}<0.01)$. There were no significant correlations between $\mathrm{H} 3 \mathrm{~K} 4 \mathrm{me} 1$ and $\mathrm{H} 3 \mathrm{~K} 4 \mathrm{me} 2$, and Ki67 $(\kappa=-0.182$, $\mathrm{p}>0.05, \kappa=-0.200, \mathrm{p}>0.05$ ) (Table III). This suggested that LSD1 may be one of the prognostic factors in MCL. 
Table III. Correlation of LSD1, H3K4me1 and H3K4me2 with Ki67 in MCL.

\begin{tabular}{|c|c|c|c|c|c|c|}
\hline \multirow[b]{2}{*}{ Ki67 } & \multicolumn{2}{|c|}{ LSD1 } & \multicolumn{2}{|c|}{$\mathrm{H} 3 \mathrm{~K} 4 \mathrm{me} 1$} & \multicolumn{2}{|c|}{$\mathrm{H} 3 \mathrm{~K} 4 \mathrm{me} 2$} \\
\hline & + & - & + & - & + & - \\
\hline+ & 10 & 0 & 2 & 8 & 0 & 10 \\
\hline- & 5 & 15 & 8 & 12 & 3 & 17 \\
\hline$\kappa$ & \multicolumn{2}{|c|}{0.667} & \multicolumn{2}{|c|}{-0.200} & \multicolumn{2}{|c|}{-0.182} \\
\hline P-value & \multicolumn{2}{|c|}{$<0.01$} & \multicolumn{2}{|c|}{$>0.05$} & \multicolumn{2}{|c|}{$>0.05$} \\
\hline
\end{tabular}

Ki67 >10\% and LSD1, H3K4me1, H3K4me2 +++ to ++++ are given as positive. LSD1, lysine-specific demethylase 1; MCL, mantle cell lymphoma.

Silencing efficiency by transfection of JeKo-1 and MOLT-4 cells with LSD1 siRNA. At $24 \mathrm{~h}$ following transfection with the indicated concentrations of LSD1 siRNA into the JeKo-1 and MOLT- 4 cells, green fluorescence in the transfected cells was observed by an inverted fluorescence microscope, and transfection efficiency was calculated, which was $90 \pm 4.34$ in the JeKo-1 and $64 \pm 2.18 \%$ in the MOLT- 4 cells $(\mathrm{n}=5$ ) (Fig. 2A). The amplification of LSD1 mRNA was decreased in a concentration-dependent manner. The gray value (to $\beta$-actin) indicated that the amplification of LSD1 was $1.02 \pm 0.17$ at $40 \mathrm{nmol} / 1$, $0.89 \pm 0.13$ at $80 \mathrm{nmol} / 1$ and $0.13 \pm 0.04$ at $120 \mathrm{nmol} / 1$ in the JeKo-1 cells, compared to the controls $\left(1.02 \pm 0.17, \chi^{2}=18.61\right.$; $\mathrm{p}<0.05$ ) (Fig. 2B). Compared to the controls, the protein expression of LSD1 deceased in a concentration-dependent manner. Following transfection with 40,80 and $120 \mathrm{nmol} / 1 \mathrm{LSD} 1$ siRNA into the JeKo-1 cells for $24 \mathrm{~h}$, the protein expression of LSD1 was decreased $0.38-, 0.21$ - and 0.15 -fold respectively. Following transfection with siRNA LSD1 at $120 \mathrm{nmol} / \mathrm{l}$ for $24 \mathrm{~h}$, LSD1 expression was decreased by $85.56 \%$ (Fig. $2 \mathrm{C}$ and D). The gray value (to $\beta$-actin) indicated that the amplification of LSD1 was $0.302 \pm 0.083$ at $30 \mathrm{nmol} / 1,0.153 \pm 0.082$ at $60 \mathrm{nmol} / 1$ and $0.091 \pm 0.024$ at $120 \mathrm{nmol} / 1$ in the MOLT- 4 cells, compared to the controls $(0.967 \pm 0.124, \mathrm{p}<0.05)$ (Fig. 2B). Following transfection with siRNA LSD1 at $120 \mathrm{nmol} / 1$ for $24 \mathrm{~h}$, LSD1 expression was decreased by $67.67 \%$ (Fig. $2 \mathrm{C}$ and D).

Silencing of LSD1 inhibits cell proliferation and promotes the apoptosis of JeKo-1 and MOLT-4 cells. The inhibition of LSD1 impaired the proliferation and induced the apoptosis of MCL cells in vitro. We performed a knockdown experiment using siRNA targeting LSD1, to further investigate the roles of LSD1 in the proliferation and apoptosis of JeKo-1 and MOLT-4 cells. The silencing of LSD1 significantly suppressed the proliferation of the JeKo- 1 and MOLT- 4 cells. The cells were transfected with various concentrations of LSD1 siRNA for $24 \mathrm{~h}$. We detected the OD value of JeKo-1 and MOLT- 4 cells by MTT assay to generate cell growth curves. In the JeKo-1 cell line, approximately $87.64 \pm 5.73 \%$ proliferation was observed following transfection with LSD1 siRNA at $40 \mathrm{nmol} / 1,70.23 \pm 2.57 \%$ at $60 \mathrm{nmol} / 1,55.41 \pm 4.24 \%$ at $80 \mathrm{nmol} / 1,38.15 \pm 2.24 \%$ at $100 \mathrm{nmol} / 1$ and $28.72 \pm 1.82 \%$ at $120 \mathrm{nmol} / \mathrm{l}$, compared to $98.42 \pm 1.12 \%$ in the controls $(0 \mathrm{nmol} / \mathrm{l})(\mathrm{p}<0.01)$. In the MOLT-4 cell line, approximately, $83.02 \pm 1.69 \%$ cell proliferation was observed following transfection with LSD1 siRNA at $30 \mathrm{nmol} / 1$, $65.72 \pm 2.16 \%$ at $60 \mathrm{nmol} / 1,41.15 \pm 2.23 \%$ at $120 \mathrm{nmol} / 1$, compared to $99.65 \pm 1.21 \%$ in the controls $(0 \mathrm{nmol} / \mathrm{l})(\mathrm{p}<0.01)$. Cell proliferation decreased along with siRNA LSD1 transfection in a concentration-dependent manner (Fig. 3A). In the JeKo-1 cells, following transfection with LSD1 siRNA at $80 \mathrm{nmol} / 1$, the cell proliferation rate was $83.56 \pm 4.51$, $54.14 \pm 4.15,33.15 \pm 5.50,25.42 \pm 7.85$ and $17.50 \pm 5.32 \%$ at 12,24 , 36, 48 and $60 \mathrm{~h}$, respectively. In the MOLT-4 cells, following transfection with LSD1 siRNA at $60 \mathrm{nmol} / 1$, the cell proliferation rate was $65.72 \pm 2.16,48.26 \pm 1.92$ and $37.86 \pm 1.66 \%$, at 24 , 48 and $72 \mathrm{~h}$, respectively. LSD1 siRNA induced the loss of cell viability in a time-dependent manner (Fig. 3B).

To verify whether the LSD1 siRNA-induced cytotoxicity was due to the induction of apoptosis, Annexin V-FITC labeling was performed following $24 \mathrm{~h}$. In the JeKo-1 cells, the apoptotic rate was $13.5 \pm 2.7,34.2 \pm 4.4$ and $44.5 \pm 6.3 \%$ following transfection with siRNA LSD1 at 40, 80 and $120 \mathrm{nmol} / \mathrm{l}$ for $24 \mathrm{~h}$, respectively, compared to the untreated cells $(4.3 \pm 1.2 \%$, $\mathrm{F}=33.41, \mathrm{p}<0.01)(\mathrm{Fig} .4 \mathrm{~A})$. In the MOLT- 4 cells, the apoptotic rate was $12.16 \pm 1.74,32.74 \pm 2.47$ and $54.64 \pm 2.58 \%$ following transfection with siRNA LSD1 at 30,60 and $120 \mathrm{nmol} / \mathrm{l}$ for $24 \mathrm{~h}$, respectively, compared to the untreated cells $(3.35 \pm 1.26 \%$, $\mathrm{p}<0.05$ ) (Fig. 4B). The apoptotic rate was increased in a concentration-dependent manner. We further investigated the expression of the apoptosis-associated proteins, pro-caspase-3, Bcl-2, C-myc and Bax. Our results revealed that the silencing of depletion of LSD1 induced the break-up of pro-caspase-3, Bcl-2 and C-myc significantly, and the upregulation of Bax. The silencing of the LSD1 gene with LSD1 siRNA in the JeKo- 1 cells at 40, 80 and $120 \mathrm{nmol} / 1$ for $24 \mathrm{~h}$ decreased Bcl-2 expression 0.59-, 0.69- and 0.89-fold, respectively. The expression of pro-caspase-3 was decreased 0.13-, 0.25- and 0.52-fold, respectively. The expression of C-myc was also decreased 0.40-, 0.49 - and 0.73-fold, respectively. Bax was increased 1.80-, 5.43- and 7.32-fold, respectively. A simlar effect was observed in the MOLT- 4 cells. In the MOLT- 4 cells, siRNA LSD1 also decreased DNMT1 expression, and increased p15 expression (Fig. 5).

Silencing of the LSD1 gene modulates histone methylation and acetylation, and downregulates cyclin D1. To examine our hypothesis, siRNA LSD1 was used to silence LSD1 gene expression, and this was found to upregulate methylated H3K4me1 and H3K4me2 in the JeKo-1 and MOLT-4 cells. The effect on histone lysine methylation was examined by immunocytochemistry using an antibody against $\mathrm{H} 3 \mathrm{~K} 4 \mathrm{mel}$ and H3K4me2. Following transfection of the JeKo-1 cells with LSD1 siRNA at 40,80 and $120 \mathrm{nmol} / 1$ for $24 \mathrm{~h}$, the expression of H3K4mel was increased 1.18-, 1.66- and 2.01-fold, respectively compared to the untreated cells. The expression of H3K4me2 was increased 1.22-, 1.73- and 2.03-fold, respectively compared to the untreated cells. However, the expression of histone trimethylated $\mathrm{H} 3 \mathrm{~K} 4 \mathrm{me} 3$ was not altered significnatly (Fig. 6). The effects of siRNA LSD1 in the MOLT- 4 cells were similar as those observed in the JeKo-1 cells (Fig. 6). These data indicate that LSD1 is probably a H3K4me1 and H3K4me2 demethylase. LSD1 siRNA increased the histone acetylation of $\mathrm{H} 3$ in the JeKo-1 and MOLT-4 
A

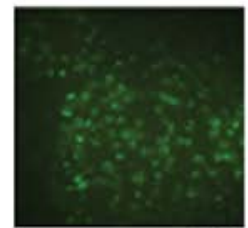

B
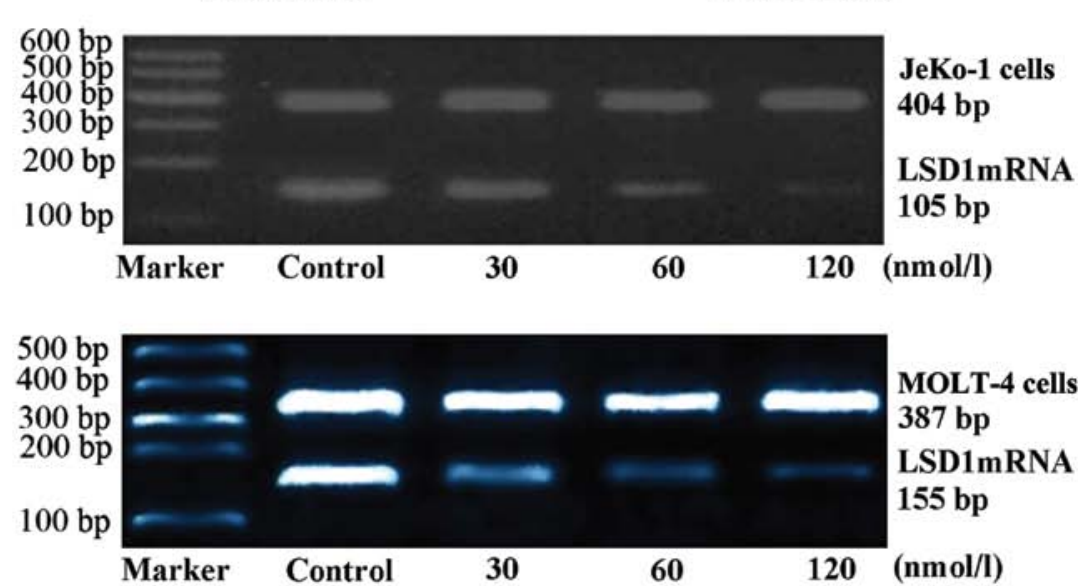

C

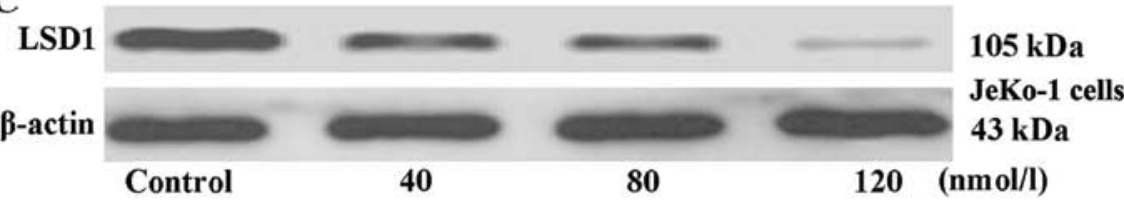

LSD1 $105 \mathrm{kDa}$
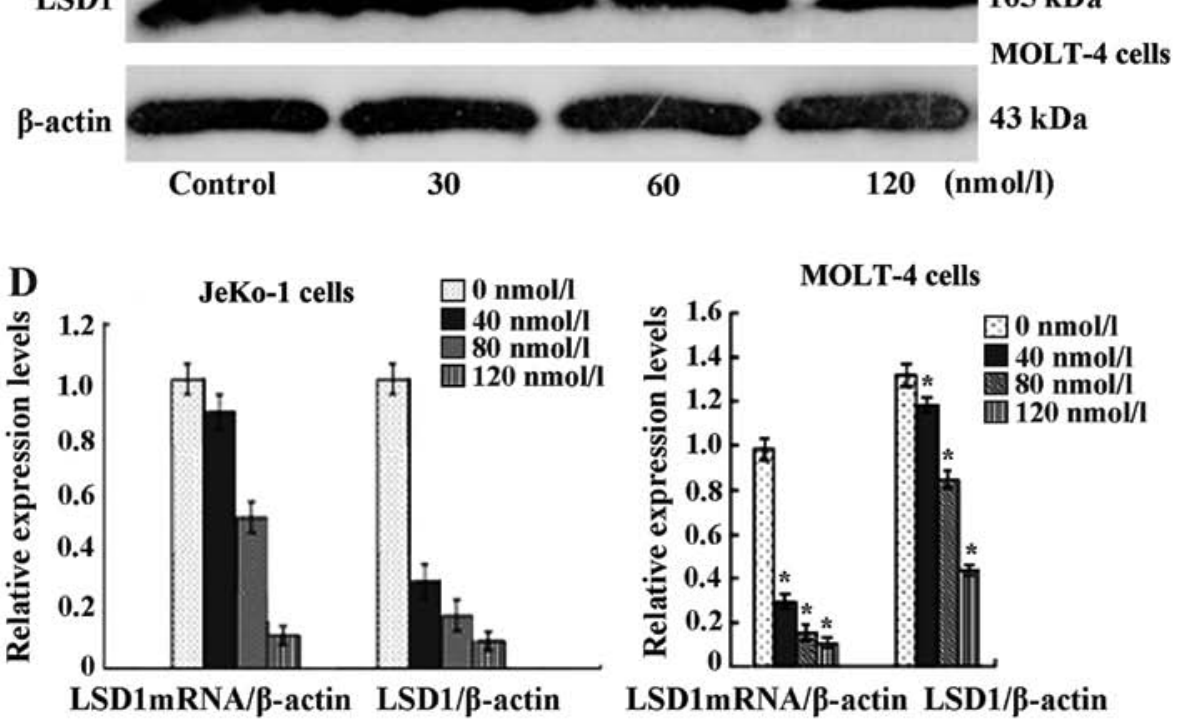

Figure 2. (A) JeKo-1 cells (left panel) were transfected with lysine-specific demethylase 1 (LSD1) small interfering RNA (siRNA) and after 24 h the transfection efficiency was examined under a fluorescence microscope. The transfection efficiency was $90 \pm 4.34 \%$ ( $\mathrm{n}=5$ ). MOLT-4 cells (right panel) were transfected with LSD1 siRNA and after $24 \mathrm{~h}$, the transfection efficiency was examined under a fluorescence microscope. The transfection efficiency was $64 \pm 2.18 \%$ ( $=5$ ). (B) mRNA expression of LSD1 following transfection with various concentrations of siRNA in JeKo-1 and MOLT-4 cells. At 24 h after transfection, the amplification of LSD1 mRNA was decreased in a concentration-dependent manner. The amplification of LSD1 was $1.02 \pm 0.17 \mathrm{at} 40 \mathrm{nmol} / 1,0.89 \pm 0.13 \mathrm{at} 80 \mathrm{nmol} / 1$, and $0.13 \pm 0.04$ at $120 \mathrm{nmol} / 1$ in the JeKo- 1 cells, compared to the controls $\left(1.02 \pm 0.17, \chi^{2}=18.61, \mathrm{p}<0.05\right.$; upper panel $)$. Compared to the controls, the protein expression of LSD1 was deceased in concentration-dependent manner. The amplification of LSD1 was $0.302 \pm 0.083$ at $30 \mathrm{nmol} / 1,0.153 \pm 0.082$ at $60 \mathrm{nmol} / 1$ and $0.091 \pm 0.024$ at $120 \mathrm{nmol} / 1$ in the MOLT-4 cells, compared to the controls $(0.967 \pm 0.124$, p $<0.05$; lower panel). (C) Following transfecton with siRNA LSD1 at the indicated concentrations for $24 \mathrm{~h}$, the protein expression of LSD1 was decreased in a concentration-dependent manner in the Jako-1 and MOLT-4 cells. (D) Relative protein density ( ${ }^{*} \mathrm{p}<0.05$ vs. $\left.0 \mathrm{nmol} / \mathrm{l}\right)$.

cells. At $24 \mathrm{~h}$ following transfection with LSD1 siRNA, the expression of histone acetylation $\mathrm{H} 3$ increased $1.25-, 1.42$ - and 1.56 -fold. As MCL is characterized by carrying the $\mathrm{t}(11 ; 14)$ (q13;q32) translocation that leads to the overexpression of cyclin D1, we further examined the effects of siRNA LSD1 on cyclin D1. The expression of cyclin D1 was decreased 0.79-, 

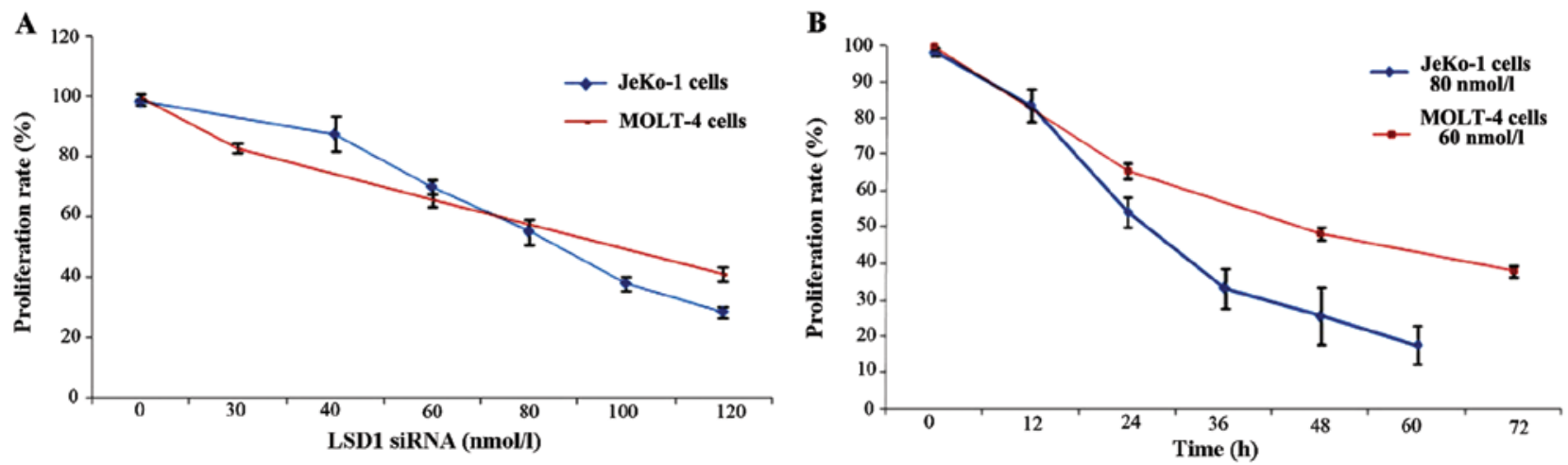

Figure 3. Lysine-specific demethylase 1 (LSD1) small interfering RNA (siRNA) inhibits the proliferation of JeKo-1 and MOLT-4 cells. Cells (1x10 ${ }^{5}$ ) were seeded into 96-well culture dishes and treated with LSD1 siRNA at various concentration and time points. Cell proliferation was measured by MTT assay (0.5 mg/ $\mathrm{ml}$ ). The spectrophotometric absorbance of the samples was determined using the Ultra Multifunctional Microplate Reader at 492 and $630 \mathrm{~nm}$ for absorbance (OD value). The inhibition ratio was also calculated. The experiment was repeated in triplicate. (A) Cell proliferation was examined inconcentrations in JeKo-1 and MOLT-4 cells transfected with various concentrations of siRNA. (B) LSD1 siRNA ( $80 \mathrm{nmol} / \mathrm{l})$ was transfected into the JeKo-1 and MOL-4 cells at different time points.

$\mathbf{A}$

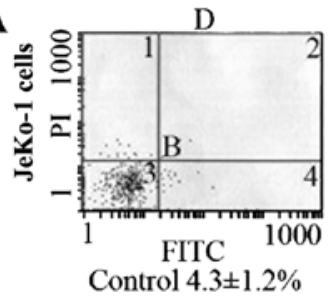

B

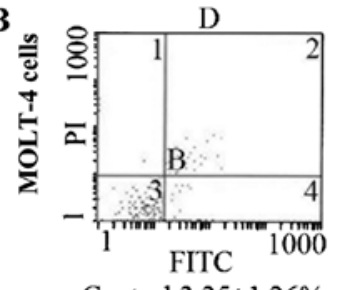

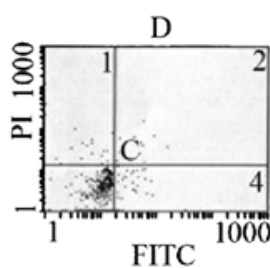

$40 \mathrm{nmol} / 113.5 \pm 2.7 \%$

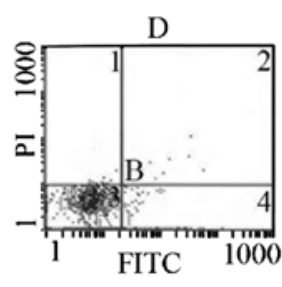

$30 \mathrm{nmol} / 1 \quad 12.16 \pm 1.74 \%$

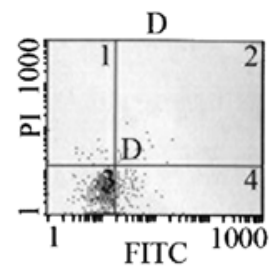

$80 \mathrm{nmol} / 134.2 \pm 4.4 \%$

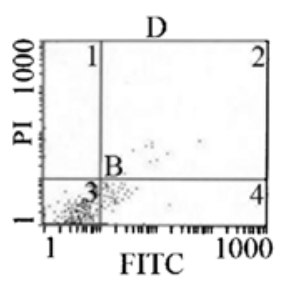

$60 \mathrm{nmol} / 1 \quad 32.74 \pm 2.47 \%$

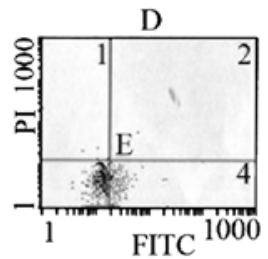

$120 \mathrm{nmol} / 144.5 \pm 6.3 \%$

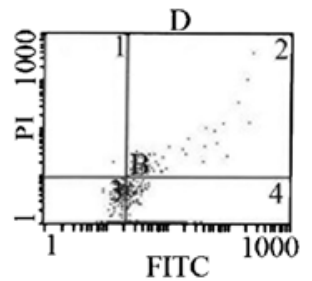

$120 \mathrm{nmol} / 154.64 \pm 2.58 \%$

Figure 4. Lysine-specific demethylase 1 (LSD1) small interfering RNA (siRNA) induced the apoptosis in (A) JeKo-1 and (B) MOLT-4 cells. Cells (1x10 $)$ were seeded into 96-well culture dishes and treated with LSD1 siRNA at the indicated concentration for $24 \mathrm{~h}$. Annexin V-propidium iodide (PI) staining was performed to determine the apoptotic cell population. Apoptosis was increased gradually following transfection with siRNA LSD1 at the indicated concentrations for $24 \mathrm{~h}$ in JeKo-1 and MOLT-4, $\mathrm{p}<0.05$. Fluorescence signals from Annenxin V-FITC and from PI are reported on the $\mathrm{x}$-axis and y-axis, respectively. Numbers shown in the 4 quadrants represent the percentage of viable (lower left quadrant), necrotic (upper right quadrant), early apoptotic (lower right quadrant) and late apoptotic (upper right quadrant) cells.

0.5 - and 0.49-fold following transfection with siRNA LSD1 at the indicated concentrations (Fig. 6).

\section{Discussion}

LSD1 was the first histone demethylase to be identified, which belongs to the flavin-dependent amine oxidase family. It is composed of 3 domains, including an N-terminal SWIRM domain, a conserved motif shared by many chromatin regulatory complexes, an amine oxidase domain (AO domain) and a C-terminal Tower domain (15-17). LSD1 cooperates with CoREST, CtBP24 corepressor complex, demethylates histone $\mathrm{H} 3 \mathrm{~K} 4$ and $\mathrm{H} 3 \mathrm{~K} 9$ through this interaction (18-20) and regulates the expression of its target gene by this epigenetic modification.

Epigenetic aberrations, including DNA methylation, histone modifications and microRNA dysregulation are now well established in the pathogenesis in many types of cancer, including ovarian cancer, some leukemia, breast, small-cell lung, colorectal, prostate, neuroblastoma and bladder cancers $(3,10,21)$, and are thought to be one of the most important mechanisms of tumorigenesis $(5,22)$. In ovarian cancer, colon cancer and prostate cancer, their gradual accumulation is associated with an advanced disease stage and grade (6,23-26). Our previous study showed that JARID1B, another histone demethylase, was highly expressed in MCL, resulting in the downregulation of histone methylation $\mathrm{H} 3 \mathrm{~K} 4 \mathrm{me} 3^{1}$ and histone $\mathrm{H} 3$ was hypomethylated at $\mathrm{H} 3 \mathrm{~K} 4$, and hypermethylated at $\mathrm{H} 3 \mathrm{~K} 9$ in leukemia patients $(26,27)$. In this study, we provide evidence that LSD1 is highly expressed, and $\mathrm{H} 3 \mathrm{~K} 4 \mathrm{me} 1$ and $\mathrm{H} 3 \mathrm{~K} 4 \mathrm{me} 2$ are expressed at low levels in MCL. A strong point of this study was the finding that the expression of LSD1 significantly positively correlated with $\mathrm{Ki} 67(\kappa=0.667, \mathrm{p}<0.01)$, which is a poor prognostic marker in MCL. It may related to the function that LSD1 promotes metastasis in various types of cancer cells (28-31). 
A

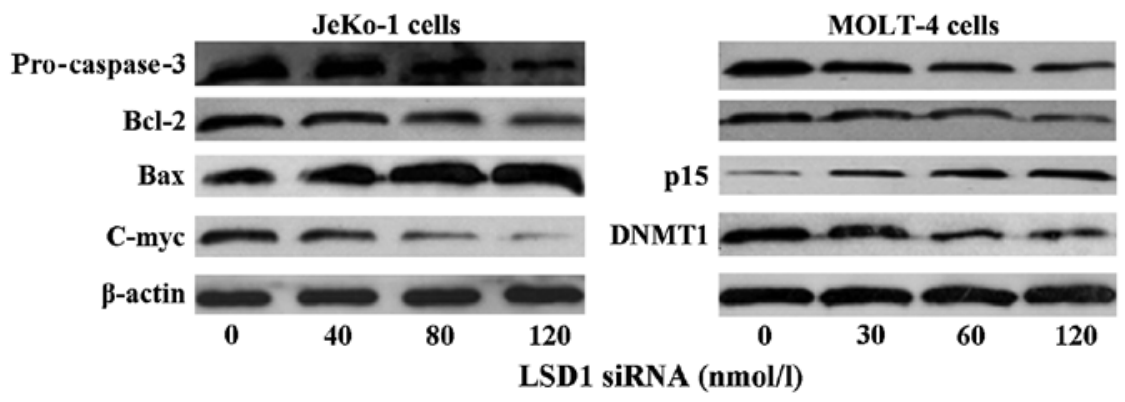

B

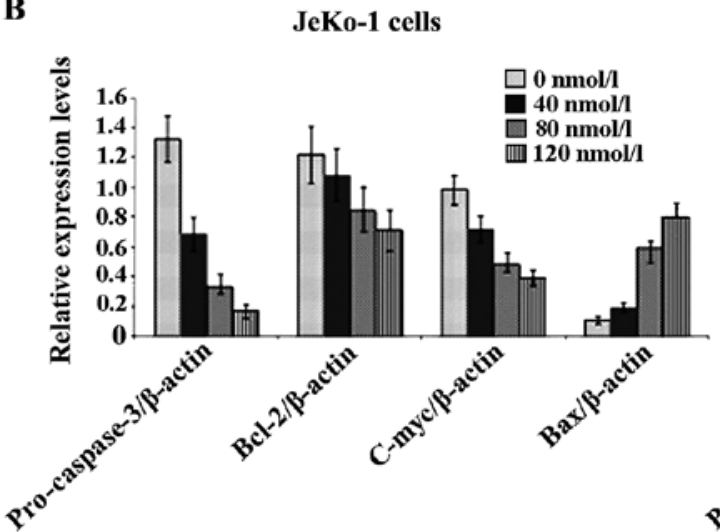

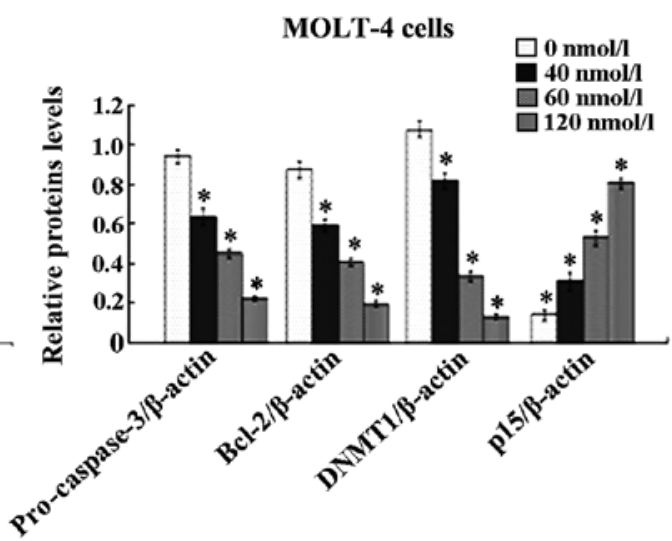

Figure 5. Lysine-specific demethylase 1 (LSD1) small interfering RNA (siRNA)-induced apoptosis is mitochondria-mediated and caspase-dependent. JeKo-1 and MOLT- 4 cells were treated for $24 \mathrm{~h}$ with siRNA LSD1 at the indicated concentrations. Following transfection with siRNA LSD1, cytosolic proteins were isolated and separated on a 12\% SDS gel, transferred onto PVDF membranes and blotted with pro-caspase-3, Bcl-2, C-myc, Bax, DNMT1 and p15 antibodies. The proteins were determined by immunoblotting using appropriate antibody. $\beta$-actin was used as a loading control. (A) siRNA LSD1 signifiantly decreased the levels of Bcl-2, pro-caspase-3 and C-myc, and upregulated Bax in JeKo-1 cells. In MOLT-4 cells, siRNA LSD1 decreased the protein expression of Bcl-2, pro-caspase-3 and DNMT1, and increased that of p15. (B) Relative protein density ("p<0.05 vs. $0 \mathrm{nmol} / \mathrm{l})$.

A

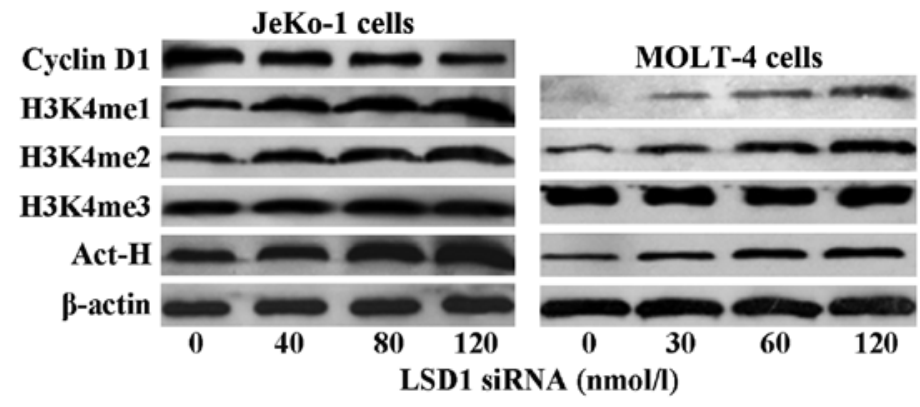

B

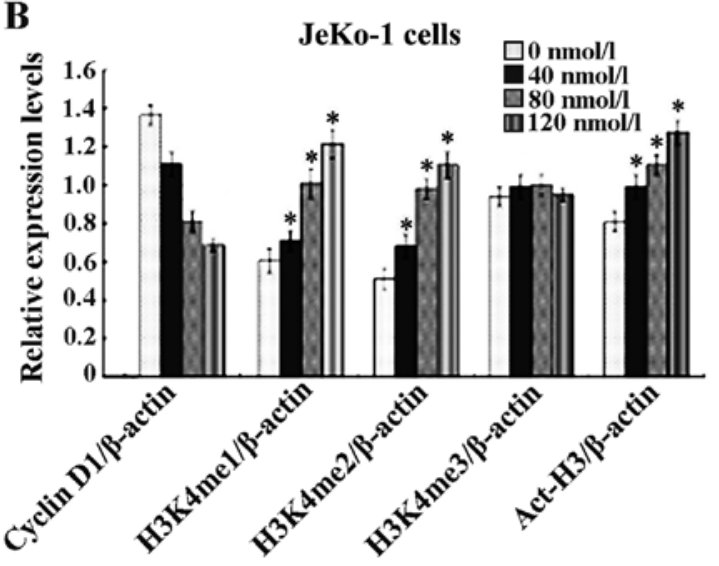

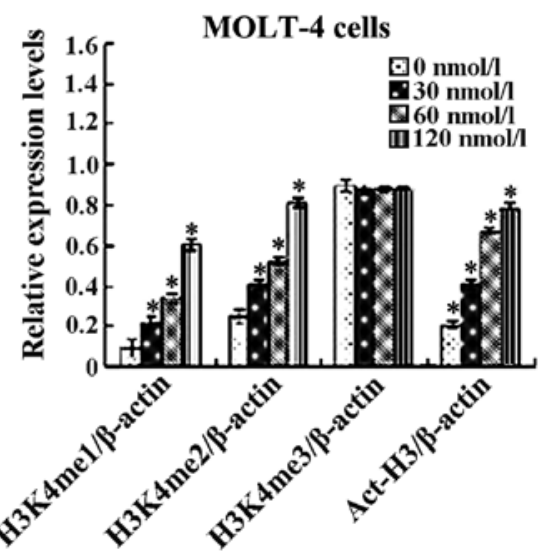

Figure 6. Lysine-specific demethylase 1 (LSD1) small interfering RNA (siRNA) modulated histone methylation and acetylation. Effect of LSD1 siRNA at various concentrations on histone modulation in JeKo-1 and MOLT-4 cells was determined by immunoblotting. Following $24 \mathrm{~h}$ LSD1 siRNA treatment, total proteins were isolated and separated on a 12\% SDS gel, transferred onto PVDF membranes and blotted with mono-, di-, trimethylation H3K4, Act-H3, and cyclin D1 antibodies. $\beta$-actin was used as a loading control. (A) LSD1 siRNA at 40, 80, $120 \mathrm{nmol} / 1$ and at 30, 60, $120 \mathrm{nmol} / 1$ upregulated histone mono-, di-methylated H3K4, acetylated $\mathrm{H} 3$ in concentration-dependent manner in JeKo-1 and MOLT-4 cells, respectively. No changes were observed in acetylated tri-methylation H3K4. Cyclin D1 expression decreased in a concentration-dependent manner in JeKo-1 cells. (B) Relative protein density ("p<0.05 vs. $0 \mathrm{nmol} / 1)$. 
The aberrant overexpression of LSD1 in MCL may make it a good candidate as a therapeutic molecular target. LSD1 promotes the proliferation, migration and invasion of various types of cancer cells $(19,31)$. In this study, siRNA LSD1 was transfected into JeKo-1 and MOLT-4 cells to silence the LSD1 gene, which resulted in a decrease in LSD1 protein and mRNA expression, and in the suppression of cell proliferation and the induction of apoptosis. A previous study also demonstrated that the inhibition of LSD1 impaired proliferation and invasiveness, and induced the apoptosis of colon cancer cells in vitro (32). LSD1 is required for cell proliferation in both a p53-dependent and -independent manner, and a deficiency in LSD1 can lead to a partial cell-cycle arrest in the G2/M phase and sensitizes cells to growth suppression induced by DNA damage or murine double minute 2 (MDM2) inhibition (33). Thge methylation of p15 increases the risk of methylation in p53, and vice versa, indicating the possible synergistic epigenetic disruption of different phases of the cell cycle or between the cell cycle and apoptosis (34). Through the enhancement of cell cycle progression, LSD1 promotes the growth of cancer cells, whereas the inhibition of LSD1 suppresses the G1 to $\mathrm{S}$ phase progression and even induces cell apoptosis $(35,36)$. Up to $88 \%$ of adult acute myelogenous leukemias or acute lymphocytic leukemias have specific methylation of the $\mathrm{p} 15^{\text {INK4b }} \mathrm{CpG}$ island. In this study, we demonstrated that the silencing of LSD1 in MOLT- 4 cells decreased DNMT1 and increased p15 expression, resulted in decreased cell proliferation and increased cell apoptosis. Our results revealed that siRNA against LSD1 decreased the expression of pro-caspase-3, Bcl-2 and C-myc and induced cell apoptosis. We demonstrated that LSD1 siRNA decreased cyclin D1 expression, which characterizes $98 \%$ of MCL cases (37). The cyclin D1 promoter contains a CpG island which can be potentially regulated by DNA methylation (38).

It is unclear whether histone methylation is also regulated by enzymes with opposing activities. LSD1, also known as AOF2 or KDM1A, was the first identified FAD-dependent histone demethylase capable of specifically demethylating mono- and dimethylated lysine 4 of histone $\mathrm{H} 3$ (H3K4me1 and H3K4me2) (39). In this study, we silenced LSD1, leading to an increase in histone methylated $\mathrm{H} 3 \mathrm{~K} 4 \mathrm{me} 1$ and $\mathrm{H} 3 \mathrm{~K} 4 \mathrm{me} 2$ and the histone acetylation of $\mathrm{H} 3$. However, the silencing of LSD1 did not affect the methylation of H3K4me3. Our previous study demonstrated that JARID1B, improved H3K4me3 (26). However, the mechanisms through which LSD1 promotes the acetyltion of $\mathrm{H} 3$ are unknown. It has been demonstrated that LSD1 is typically found in association with HDAC1/2, Co-REST, BHC80 and BRAF35 (39). LSD1 has been proposed to demethylate its histone substrate that requires the intimate collaboration between LSD1 and HDAC1/2 $(17,40,41)$. Treatment with zinc-dependent class I/II HDAC inhibitors has been shown to markedly diminish the activity of LSD1 in breast cancer cells. HDAC inhibitor and LSD1 inhibitor cooperate to increase both histone methylation and acetylation, indicating the synergistic effects of the combination of DNA methyltransferase and HDAC inhibitors in re-expressing epigenetically silenced genes in cancer cells, and leading to clinical responses in patients with leukemia (42). In breast cancer cells, it leads to significant synergy in growth inhibition when used in combination (43). These observations indicate that histone demethylation is an important component of the activity of HDAC inhibitors.

In conclusion, in this study, we demonstrate that epigenetic aberration occurs in MCL, in which is LSD1 overexpressed and the methylation of $\mathrm{H} 3 \mathrm{~K} 4 \mathrm{me} 1$ and $\mathrm{H} 3 \mathrm{~K} 4 \mathrm{me} 2$ is downregulated. LSD1 may thus be a prognostic factor, as it positively correlated with Ki67. LSD1 may be a marker of carcinogenesis. The silencing of the LSD1 gene led to the downregulation of LSD1, and the upregulation of $\mathrm{H} 3 \mathrm{~K} 4 \mathrm{me} 1$ and $\mathrm{H} 3 \mathrm{~K} 4 \mathrm{me} 2$. It also led to the accumulation of histone acetylation $\mathrm{H} 3$, and the inhibition of DNMT1 but increased p15, which are associated with the 5 ' regions of virtually all active genes and positively correlate with transcription rates. The silencing of the LSD1 gene induced cell apoptosis and inhibited cell proliferation. LSD1 may thus be an important alternative target for the treament of MCL.

\section{Acknowledgements}

This study was partly supported by a Grant-in-Aid from the Foundation of Science and Technology of Fujian Medical University, Fujian, China (no. FZS08018), Science Research Foundation of Ministry of Health, United Fujian Provincial Health, and Education Project for Tackling the Key Research, P.R. China (WKJ2008-2-55), Science Research Foundation of Fujian, P.R. China (2012J01420), Medical Innovations Research Foundation of Fujian Province, P.R. China (2012-CX-32) and the major project funded by R\&D institutions of Fujain (2012I2004).

\section{References}

1. Seligson DB, Horvath S, McBrian MA, Mah V, Yu H, Tze S, Wang Q, Chia D, Goodglick L and Kurdistani SK: Global levels of histone modifications predict prognosis in different cancers. Am J Pathol 174: 1619-1628, 2009.

2. Lim S, Metzger E, Schüle R, Kirfel J and Buettner R: Epigenetic regulation of cancer growth by histone demethylases. Int $\mathrm{J}$ Cancer 127: 1991-1998, 2010.

3. Hayami S, Kelly JD, Cho HS, Yoshimatsu M, Unoki M, Tsunoda T, Field HI, Neal DE, Yamaue H, Ponder BA, et al: Overexpression of LSD1 contributes to human carcinogenesis through chromatin regulation in various cancers. Int $\mathrm{J}$ Cancer 128: 574-586, 2011.

4. Kahl P, Gullotti L, Heukamp LC, Wolf S, Friedrichs N, Vorreuther R, Solleder G, Bastian PJ, Ellinger J, Metzger E, et al: Androgen receptor coactivators lysine-specific histone demethylase 1 and four and a half LIM domain protein 2 predict risk of prostate cancer recurrence. Cancer Res 66: 11341-11347, 2006.

5. Lim S, Janzer A, Becker A, Zimmer A, Schüle R, Buettner R and Kirfel J: Lysine-specific demethylase 1 (LSD1) is highly expressed in ER-negative breast cancers and a biomarker predicting aggressive biology. Carcinogenesis 31: 512-520, 2010.

6. Schulte JH, Lim S, Schramm A, Friedrichs N, Koster J, Versteeg R, Ora I, Pajtler K, Klein-Hitpass L, Kuhfittig-Kulle S, et al: Lysine-specific demethylase 1 is strongly expressed in poorly differentiated neuroblastoma: implications for therapy. Cancer Res 69: 2065-2071, 2009.

7. Singh MM, Manton CA, Bhat KP, Tsai WW, Aldape K, Barton MC and Chandra J: Inhibition of LSD1 sensitizes glioblastoma cells to histone deacetylase inhibitors. Neuro-oncol 13: 894-903, 2011.

8. Schenk T, Chen WC, Göllner S, Howell L, Jin L, Hebestreit K, Klein HU, Popescu AC, Burnett A, Mills K, et al: Inhibition of the LSD1 (KDM1A) demethylase reactivates the all-trans-retinoic acid differentiation pathway in acute myeloid leukemia. Nat Med 18: 605-611, 2012. 
9. Culhane JC and Cole PA: LSD1 and the chemistry of histone demethylation. Curr Opin Chem Biol 11: 561-568, 2007.

10. Rotili D and Mai A: Targeting histone demethylases: a new avenue for the fight against cancer. Genes Cancer 2: 663-679, 2011.

11. Pui CH, Relling MV and Downing JR: Acute lymphoblastic leukemia. N Engl J Med 350: 1535-1548, 2004.

12. Li Y, Deng C, Hu X, Patel B, Fu X, Qiu Y, Brand M, Zhao K and Huang S: Dynamic interaction between TAL1 oncoprotein and LSD1 regulates TAL1 function in hematopoiesis and leukemogenesis. Oncogene 31: 5007-5018, 2012.

13. Alinari L, Christian B and Baiocchi RA: Novel targeted therapies for mantle cell lymphoma. Oncotarget 3: 203-211, 2012.

14. Marks DI and Rowntree C: Management of adults with T-cell lymphoblastic leukemia. Blood 129: 1134-1142, 2017.

15. Forneris F, Binda C, Vanoni MA, Mattevi A and Battaglioli E: Histone demethylation catalysed by LSD1 is a flavin-dependent oxidative process. FEBS Lett 579: 2203-2207, 2005.

16. Shi Y and Whetstine JR: Dynamic regulation of histone lysine methylation by demethylases. Mol Cell 25: 1-14, 2007.

17. Yang M, Culhane JC, Szewczuk LM, Gocke CB, Brautigam CA Tomchick DR, Machius M, Cole PA and Yu H: Structural basis of histone demethylation by LSD1 revealed by suicide inactivation. Nat Struct Mol Biol 14: 535-539, 2007.

18. Lee MG, Wynder C, Cooch N and Shiekhattar R: An essential role for CoREST in nucleosomal histone 3 lysine 4 demethylation. Nature 437: 432-435, 2005.

19. Gatta R and Mantovani R: NF-Y substitutes H2A-H2B on active cell-cycle promoters: recruitment of CoREST-KDM1 and fine-tuning of $\mathrm{H} 3$ methylations. Nucleic Acids Res 36 : 6592-6607, 2008.

20. Lv T, Yuan D, Miao X, Lv Y, Zhan P, Shen X and Song Y: Over-expression of LSD1 promotes proliferation, migration and invasion in non-small cell lung cancer. PLoS One 7: e35065, 2012.

21. Wei SH, Balch $\mathrm{C}$, Paik HH, Kim YS, Baldwin RL, Liyanarachchi S, Li L, Wang Z, Wan JC, Davuluri RV, et al: Prognostic DNA methylation biomarkers in ovarian cancer. Clin Cancer Res 12: 2788-2794, 2006.

22. Tsai HC and Baylin SB: Cancer epigenetics: linking basic biology to clinical medicine. Cell Res 21: 502-517, 2011.

23. Suikki HE, Kujala PM, Tammela TL, van Weerden WM, Vessella RL and Visakorpi T: Genetic alterations and changes in expression of histone demethylases in prostate cancer. Prostate 70: 889-898, 2010

24. Balch C, Fang F, Matei DE, Huang TH and Nephew KP: Minireview: epigenetic changes in ovarian cancer. Endocrinology 150: 4003-4011, 2009.

25. Asadollahi R, Hyde CA and Zhong XY: Epigenetics of ovarian cancer: from the lab to the clinic. Gynecol Oncol 118: 81-87, 2010

26. Su H, Ma X, Huang Y, Han H, Zou Y and Huang W: JARID1B deletion induced apoptosis in JeKo-1 and HL-60 cell lines. Int J Clin Exp Pathol 8: 171-183, 2015.

27. Zou Y, Ma X, Huang Y, Hong L and Chiao JW: Effect of phenylhexyl isothiocyanate on aberrant histone $\mathrm{H} 3$ methylation in primary human acute leukemia. J Hematol Oncol 5: 36-42, 2012.

28. Willmann D, Lim S, Wetzel S, Metzger E, Jandausch A, Wilk W, Jung M, Forne I, Imhof A, Janzer A, et al: Impairment of prostate cancer cell growth by a selective and reversible lysine-specific demethylase 1 inhibitor. Int J Cancer 131: 2704-2709, 2012.

29. Jin L, Hanigan CL, Wu Y, Wang W, Park BH, Woster PM and Casero RA Jr: Loss of Lysine-Specific Demethylase 1 (LSD1) suppresses growth and alters gene expression of human colon cancer cells in a p53 and DNA methyltransferase 1 (DNMT1) independent manner. Biochem J 449: 459-468, 2013.
30. Zhao ZK, Dong P, Gu J, Chen L, Zhuang M, Lu WJ, Wang DR and Liu YB: Overexpression of LSD1 in hepatocellular carcinoma: a latent target for the diagnosis and therapy of hepatoma. Tumour Biol 34: 173-180, 2013.

31. Cho HS, Suzuki T, Dohmae N, Hayami S, Unoki M, Yoshimatsu M, Toyokawa G, Takawa M, Chen T, Kurash JK, et al: Demethylation of RB regulator MYPT1 by histone demethylase LSD1 promotes cell cycle progression in cancer cells. Cancer Res 71: 655-660, 2011.

32. Ding J, Zhang ZM, Xia Y, Liao GQ, Pan Y, Liu S, Zhang Y and Yan ZS: LSD1-mediated epigenetic modification contributes to proliferation and metastasis of colon cancer. Br J Cancer 109: 994-1003, 2013.

33. Scoumanne A and Chen X: The lysine-specific demethylase 1 is required for cell proliferation in both p53-dependent and -independent manners. J Biol Chem 282: 15471-15475, 2007.

34. Bodoor K, Haddad Y, Alkhateeb A, Al-Abbadi A, Dowairi M, Magableh A, Bsoul N, Ghabkari A and Bodoor K: DNA hypermethylation of cell cycle (p15 and p16) and apoptotic (p14, p53, DAPK and TMS1) genes in peripheral blood of leukemia patients. Asian Pac J Cancer Prev 15: 75-84, 2014.

35. Wang J, Hevi S, Kurash JK, Lei H, Gay F, Bajko J, Su H, Sun W, Chang H, Xu G, et al: The lysine demethylase LSD1 (KDM1) is required for maintenance of global DNA methylation. Nat Genet 41: 125-129, 2009.

36. Wen L, Chen Y, Zeng LL, Zhao F, Li R, Liu Y and Zhang C: Triptolide induces cell-cycle arrest and apoptosis of human multiple myeloma cells in vitro via altering expression of histone demethylase LSD1 and JMJD2B. Acta Pharmacol Sin 33: 109-119, 2012.

37. Sabattini E, Bacci F, Sagramoso C and Pileri SA: WHO classification of tumours of haematopoietic and lymphoid tissues in 2008: an overview. Pathologica 102: 83-87, 2010.

38. Kitazawa S, Kitazawa R and Maeda S: Transcriptional regulation of rat cyclin D1 gene by $\mathrm{CpG}$ methylation status in promoter region. J Biol Chem 274: 28787-28793, 1999.

39. Shi Y, Lan F, Matson C, Mulligan P, Whetstine JR, Cole PA, Casero RA and Shi Y: Histone demethylation mediated by the nuclear amine oxidase homolog LSD1. Cell 119: 941-953, 2004.

40. Shi YJ, Matson C, Lan F, Iwase S, Baba T and Shi Y: Regulation of LSD1 histone demethylase activity by its associated factors. Mol Cell 19: 857-864, 2005.

41. Lan F, Collins RE, De Cegli R, Alpatov R, Horton JR, Shi X, Gozani O, Cheng X and Shi Y: Recognition of unmethylated histone $\mathrm{H} 3$ lysine 4 links BHC80 to LSD1-mediated gene repression. Nature 448: 718-722, 2007.

42. Gore SD, Baylin S, Sugar E, Carraway H, Miller CB, Carducci M, Grever M, Galm O, Dauses T, Karp JE, et al: Combined DNA methyltransferase and histone deacetylase inhibition in the treatment of myeloid neoplasms. Cancer Res 66: 6361-6369, 2006.

43. Huang Y, Vasilatos SN, Boric L, Shaw PG and Davidson NE: Inhibitors of histone demethylation and histone deacetylation cooperate in regulating gene expression and inhibiting growth in human breast cancer cells. Breast Cancer Res Treat 131: 777-789, 2012. 